\title{
From Culturalism to Transculturalism
}

\author{
Jeff Lewis
}

\section{The Cultural Dynamic}

Cultural studies has a complex and dynamic genealogy. We can trace various lineages through social theory, sociology, anthropology, history, politics, and various modes of aesthetics. However, the constellation of these somewhat indefinite elements is frequently attributed to Raymond Williams and the Birmingham Centre for Contemporary Cultural Studies (see Hall, "Cultural Studies"; Turner; Grossberg; Bennett; Storey; Lewis). Williams's concept of "cultural studies," along with Richard Johnson's broader notion of "culturalism," distinguished a mode of analysis which could integrate an anthropological interest in the popular arts and artifacts with a reformist social and political agenda. Through various refinements, most particularly the more sophisticated application of Stuart Hall's interpretation of Althusserian ideology and Gramscian hegemony ("Rediscovery of Ideology"), Birmingham cultural studies exerted an astonishing influence over the evolving (mis)fortunes of the humanities and social sciences in the English-speaking world. Even in the United States, with its own quite distinct understandings of the problematic of "culture," Birmingham style cultural studies was able to attach itself to local permutations of poststructural and postmodern theory, providing, among other things, a reinvigorated vocabulary of heuristic dispute-one which productively engaged with America's ongoing consternations over race, the politics of pluralism

Jeff Lewis is Senior Lecturer in media and cultural studies in the School of Applied Communication, RMIT University, Melbourne, Australia. He is the author of Cultural Studies (Sage, 2002). E-mail: jeff.lewis@rmit.edu.au. 
and notions of national culture.

More broadly, however, this constellation of the various lineages which led to a distinctive cultural studies illuminated new pathways and new possibilities for a cross- or transdisciplinary approach to the specific field of knowledge. In his review of the Birmingham legacy, Stuart Hall has argued that cultural studies has always had at its core a political agenda ("Cultural Studies"). The post-Birmingham period has presented new challenges to the notion of ideology, structure, and hegemony, with many cultural theorists preferring to centralize a more generic definition of power and power relationships. Foucault substantiates this idea when he refers to the pervasiveness of power through the stratum and sub-stratum of social and personal relationships (see Discipline and Punish and History of Sexuality). The precise nature of this power, however, remains decidedly problematic, as Foucault's pronouncements have been deployed in the interests of two quite divergent modes of post-hegemony, post-ideology cultural movements. In the first instance, it has been taken up by a broad field of analysts interested in defining, even welcoming, a new historical epoch which would facilitate the radical expansion of human identity and expressive subjectivities. The second area in which Foucault's ideas have been adapted is in the area of cultural policy or "cultural civics."

My aim in this paper is to examine critically these recent developments in cultural studies in terms of a post-Gramscian cultural dynamic. This is not to suggest that the Gramscian paradigm is exhausted and I acknowledge that there are many very notable writers in the field who advocate the restoration (continuation) of a Gramscian theoretic (see Storey, McRobbie, Grossberg). My argument here is simply that the most recent incarnations of the self-defining cultural studies movement have centered on two quite specific readings of Foucault. In order to advance our understanding of culture it seems necessary to examine these readings, most especially as cultural studies seeks to establish itself as the evolutionary descendant of the traditional disciplines. The current essay, in fact, suggests an alternative to the Foucaultian cultural dichotomy, one which seeks to maximize the heuristic efficacy of hegemony theory and poststructuralism. To this extent, I suggest that the concept of "transculturalism" takes us beyond Johnson's original notion of "culturalism" through the integration of a political aesthetics with a cultural civics.

\section{From Postmodern to Posthuman}

The poststructural and postmodern critiques of Gramscian theory have been well canvassed. However, it is worth recalling some of the more prominent objections to structuralist notions of power, ideology, and hegemony. Thus, for the poststructural/postmodern cultural theorist-

- Power is basically unstable and interchangeable. It is never fixed in structure but is experienced at the level of the individual body. Power is inevitably challenged at the moment of its appearance; it is always changing, mutating, being transformed. 
- Power is shaped through language which is itself incomplete and always in transition.

- Notions of hegemony and ideology, even as they are construed as "negotiable," falsify the dispersed and incomplete nature of language.

- If truth exists at all it is only a locally constituted phenomenon that operates temporarily and can never be universal.

- Without an origin, center, or ultimate cause, language is predisposed toward the margins.

- Culture is formed in language so it too is transitory, unstable, and dynamic.

- Culture thus becomes a resource for identity liberation, diversity, free imagining, and expressiveness. The goal of the cultural critic should be to enhance the liberational space of the individual subject.

- Systems and structures of any kind are to be abhorred. Marxism, for example, merely substitutes one dominant or normative institution for another. The postmodern cultural critic, therefore, seeks "alternatives" through the margins, the personal, the sensual or pleasurable, the (individuated) popular, the body, the fragmented self, the other, the diasporic, and the multicultural.

Identity politics are centralized in a celebrational postmodernism. Even Gramsci's notion of organic intellectuals, which certainly widened the liberational ambit of Marx and Althusser, seems excessively limiting to the postmodernists. The subject is liberated in postmodern culture through the complete extinguishment of social or collective imperatives. The subject is free-flowing, selecting, unhindered. S/he cannot be defined except through self-reflexivities and self-determinations. There is no fixed center, no ultimate reference by which the subject might be measured or estimated. The institutional ascriptions of race, class, sexuality, gender, age, and geography are deconstructed and hence neutralized by a cultural studies which privileges the margins and the particulate over the formative and determinant. Individual identity and personal pleasure overwhelm the austerities and expectations of modernism, advocating a new morality and a new way of aestheticizing relationships which are no longer territorialized by certainty (see Deleuze and Guattari, Giddens).

This mode of analytical advocacy has clearly distinguished itself from the humanist precepts which underpin modernist politics. According to a celebrational postmodern theoretic, humanism is another form of institutional or normative containment, one which generally disguises political elitism within a collectivist discourse. That is, humanism, most particularly as it attaches itself to the state, democracy and capitalism, expresses the interests of plutocratic, white heterosexual males under the guise of a general "social benefit." As with Benthamite and Millsian utilitarianism, humanism seeks to mediate the social good as an assembly of individual gratifications, pleasures, and prosperities. Zolo, along with other recent 
analysts of modern liberalism and democracy, point out that this mediation simply manifests itself as a highly differentiated and hierarchical social order.

The theoretics of posthumanism breaks entirely with this ideological nexus, seeking to establish a politics which is constituted around the radicalization of self, reality, and knowledge. Writers like Jean Baudrillard have, of course, identified these radical disjunctures through a new kind of critical pessimism which is associated with contemporary televisual culture. Baudrillard's pessimism is not shared by many advocates of posthumanism who herald the epoch in terms of its liberational potential. For these theorists there can be no restoration of a generalized human experience since all experiences are unique and highly individualized. Any attempts to produce a generalized ethic or political principle, indeed any attempts to produce a generalized community, necessarily transgress the interests of individuals (see Nancy). For these radical theorists the past must be ruptured and the future must be seized in a language war that can have no completion and no consummation. For posthumanists, history and culture are characterized by agonism and by the exertion of dominant groups; only through a form of radical separationism can subjects be truly liberated from the homogenizing and normativizing excesses of these dominant groups.

Posthumanism is constructed out of a sense of dismay and disquiet. Like other postmodernists, though without the critical pessimism of Baudrillard or the sentimentalism of Charles Jencks, posthumanism abandons the possibility of a meaningful or fixed communicative form. Rather, communication is perpetually self-shattering, constituted through ephemera, transience, and the radical fragmentation of subjectivity. For authors like Donna Haraway posthumanism offers the possibility of an evolutionary leap, a move toward a new cyborgian identity that is not ossified by the precepts of gender, age, ethnicity, or sexuality. Judith Halberstam and Ira Livingston celebrate the disillusion that is inherent in posthumanism since it provides the conduit for a new and more radical social conceit:

The gridlock of signifiers and signifieds at the juncture of gender, class, ethnicity and sexuality in the night world of voguing is a traffic jam of posthuman proportions, where the drivers may as well abandon their vehicles. The Human wanders, lost, into a maze of sex changes, wardrobe changes, make-overs, and cover versions that imbricate human reality into posthuman realness. (7)

The obliteration of origin in a postmodern poetica is unmistakable. Such apocalyptic hedonism resonates in much of the science fiction futurism from which posthuman theoretics draw their inspiration. However, a vision of radical separationism and its prescient "realness" critically under acknowledges the processes of meaning-making which continue to drive and motivate contemporary culture(s). Separationism, displeasure, and non-meaning are certainly present in current discourses and media experiences, but so too are the communalizing and communicative experiences which continue to congregate around discourses like love, freedom, nation, democracy, pleasure, family, television, and music. We continue, that is, to congregate around our various formations of culture and meaning. Thus, just as hegemony theory and 
structuralism more broadly might overstate the possibilities of systematic communication, so the separationists overstate its implausibility. The corollary of this sort of separationism is the ultimate individuation of all human experience and the abandonment of any communicative or systematizing semiotic flow.

\section{The New Civics}

The Foucaultian path to separationism is marked by the French philosopher's somewhat suppressed but recurring devotion to personal politics and an aestheticized anarchicism. Even so, a number of theorists have adapted Foucault's broader interest in the operations of the state and "governmentality" in order to take cultural studies in a quite different direction from the separationists: that is, toward a new form of cultural civics. For these critics Foucault's work is clearly dissociated from the lineage of Bakhtin and the radical pschoanalysts like de Certeau, Deleuze, and Guattari on the one hand, and the aesthetic postmodernists on the other. Remarkably, in fact, these theorists frequently couple an interest in Habermas's re-vitalized public sphere (see The Philosophical Discourse of Modernity and The Structural Transformation of the Public Sphere) with Foucault's governmentality thesis. I say remarkable because Habermas himself distinguishes his own concerns and intellectual heritage from Foucault's, which he sees as fundamentally embedded in the project of postmodernism (see "Taking Aim").

Specifically, however, Foucault's notion of governmentality may be regarded as a form of material management which defines itself historically as a mode of social organization. Governmentality refers to a modernist deployment of managerial strategies-

Government is defined as a right manner of disposing things so as to lead not to the form of the common good, as the jurists' texts would have said, but to an end which is "convenient" for each of the things that are to be governed. This implies a plurality of specific aims: for instance, government will have to ensure that the greatest possible quantity of wealth is produced, that the people are provided with sufficient means of subsistence, that the population is enabled to multiply. . . . . [W]ith government it is not a matter of imposing laws on men, but of disposing things: that is to say, of employing tactics rather than laws, and even of using laws themselves as tactics - to arrange things in such a way that, through a certain number of means, such and such ends may be achieved. ("Governmentality" 95)

Foucault reviews the notion in various lectures, seminars, and interviews, suggesting at one point that the "contact between technologies of domination of others and those of the self I call governmentality" ("Technologies of the Self" 19). In this discussion, however, Foucault concedes that his study of governmentality has overemphasized tactics of domination over those of self-management. In his essay "Technologies of the Self" Foucault makes clear that subjects employ various "tactics" (technologies, techniques) in order to govern themselves. To this extent, governmentality is not merely about institutionally elected governments, but rather about the ubiquity of governance, management, and control. It should also be 
emphasized that Foucault's application of the concept of governmentality is historically focused, designed to distinguish the political practices and "technologies" of the Enlightenment (and modernity) from previous epoches.

Tony Bennett, nevertheless, is undeterred in his adaptation of Foucault's concept for a polemical account of contemporary cultural studies. Bennett expresses his deep dissatisfaction with the Gramscian approach to culture and cultural analysis, arguing that studies based around ideology and hegemony tend to reproduce simplistic notions of a center of power. Foucault's arguments, by contrast, treat power as decentralized and pervasive in all human relations. Bennett makes several claims against a cultural studies which is preoccupied with theoretical and representational issues. A policy driven cultural studies would redress a number of the problems that continue to limit the practical efficacy of cultural studies and cultural politics. To this extent, a policy-based cultural studies would-

1. Focus on institutions and institutional practices.

2. Recognize that cultural studies is practised within educational institutions which are in turn instruments of government and governmentality.

3. Acknowledge that cultural studies is not a renegade activity but exists within the framework of governmentality and so engages in specific regulatory practices (e.g. what is to be studied, what is not to be studied).

4. Interrogate various technologies of power as they are exercised through institutional practices.

Bennett's essay, produced out of the Australian Key Centre for Cultural and Media Policy, polemicizes the issue of cultural policy analysis in contemporary cultural studies. Along with other scholars associated with the Centre-Ian Hunter, Colin Mercer, and Stuart Cunningham-Bennett maintains that questions of policy and governmentality need to be central to the cultural studies project if it is to reach beyond the limited borders of textual analysis.

Similarly, Jim McGuigan argues that cultural studies' infatuation with language and discourse theory has led to an overemphasis on textual shaping and consumption (Cultural Populism). According to McGuigan, the deviation of cultural inquiry into various forms of cultural populism has limited its critical efficacy, as it surrenders to the reactionary interests of global capitalism. McGuigan, in fact, questions not only the populism of cultural analysts like John Fiske (see Media Matters and Understanding Popular Culture), but also a policy focus which is not grounded in normative critical values. To this extent, McGuigan distinguishes his own work from that of authors like Bennett. McGuigan presents his own analysis in terms of critical values of "democratic egalitarianism" which are applied to a number of concrete and substantive issues of cultural policy, including questions of evaluative judgment and public administration, culture, economy, geography and history, cultural identity, citizenship, censorship, and morality (Culture and the Public Sphere 177; see also Kellner). For McGuigan, Habermas's notion of a consensual 
communicative action within the public sphere provides the basis for understanding the actual conditions of ordinary people's everyday struggles. The ultimate question for cultural studies, McGuigan argues, is how to construct an expressive citizenship.

\section{The Policy Debate}

Borrowing from Simon During, we can identify three levels within the cultural policy debate:

1. Policy should be studied in cultural analysis.

2. Culture is characterized by governmentality and regulatory processes.

3. Policy should be the central focus of cultural studies. (480)

There can be little argument with the first level of this debate-that policy issues should be part of the cultural studies ambit. It is certainly true that some areas of cultural studies restrict their analysis to problems of aesthetics and representation, and are less interested in issues of power and injustice. It is equally true, however, that many cultural analysts enter public and policy debates quite directly, applying modes of Gramscian or Foucaultian discourse-based cultural analysis. Stuart Hall and Edward Said, for example, have often engaged in matters of governmental policy formulation as well as direct political action. Hall makes it clear that his theoretical work is always and necessarily focused toward practical political outcomes (see "Cultural Studies," "The Local and the Global," and "Old and New Identities"). Hall's explicit criticism of Thatcherism in England and Said's opposition to U.S. foreign policy initiatives in the Middle East demonstrate clear continuities between various forms of textual analysis and participation in public policy debates. Of course, Bennett objects to the putative oppositionalism of Gramscianstyle cultural studies, but it is nevertheless clear that cultural studies critique reaches well beyond a simple opposition for opposition's sake. Through its Gramscian and Foucaultian incarnations cultural studies continues to make major contributions to the ways in which culture and politics can be considered; in this sense, cultural studies can be critical (or "negative") as well as offering positive suggestions for policy formulation.

The problem for Bennett's approach - and here we encounter the second level of the policy debate-is that the whole notion of governmentality is so complete that it appears inescapable. In other words, there seems to be nothing an individual subject can achieve through a critical or ideological distance from the processes of being governed or regulated. In this sense, opposition, resistance, and even rejection seem merely to be cultural articulations that are comfortably accommodated within the general context of citizenship and cultural civics. While at one level this may seem reassuring, at another level the risk of serious political dilution emerges since radical resistance becomes fatuous, meaningless, or absurd in Bennett's schema. 
There seems little value in a scholar (or any other subject) resisting or rejecting the threat of injustice or oppression except through the available mechanisms of democratic participation and regulation. Protest must be contained within a general discourse of participation since "to be a citizen" is the complete lexicon of rights and political determinations. In Bennett's cultural civics, there appears to be no legitimate subjectivity that is not contained within the borders of the citizenry.

At the third level of this debate, then, it seems clear that the situating of policy at the center of cultural studies seriously limits the possibilities of thinking new thoughts and exploring new horizons of culture and cultural politics. Specifically, the centralization of policy, governmentality, and citizenship privileges the state and its right to govern, control, and regulate. It tends to reinscribe the problems associated with representative democracy and the excesses of statehood and nation. That is, cultural policy studies tend to fix their liberation in the constituency of the nation-state; the nation is restored against the flow of diversity and multitudinous cultural forms associated with globalization, identity, and cultural difference; the policy approach tends to override the great diversity of social and spatial scales in which power operates. More particularly, cultural policy studies are predisposed toward regulation and protection which inevitably compromises or diminishes the potentialities of new modes of cultural expression, subjectivity, and identity. In repudiating postmodernist interests in difference and customized forms of pleasure and emancipation, the national policy approach frequently threatens to confirm as it restores the authority and homogenizing tendencies of the state. The pragmatism which is often celebrated by cultural policy studies may be viewed more broadly as an unmitigating faith in governance and the humanist ideal, a faith which inevitably reconstitutes the limiting effects of rationalized order and the universalization of individual and community desires - a faith, that is, in the social collective over the personal.

Along these lines, Fredric Jameson claims that the policy-primacy approach is highly localized, emerging in a context of high levels of state intervention ("On 'Cultural Studies"'). While such policy studies may be pertinent to a country like Australia, Jameson argues, they have far less relevance in the United States where there is little ideological or historical support for state engagement in cultural activities. Adding to this, we might suggest that this highly localized conception of the state and state regulation seriously limits the policy scholars' view of broader, global, cultural issues. Simon During suggests something similar in his discussion of the policy debate, claiming that Australian policy scholars have been well positioned to contribute to government policy formulation designed to support local culture and cultural industries: "But this means that the hot issues on the American culture/government interface-censorship, and the withholding of public funding for so-called obscene or blasphemous works, the attack on multiculturalism, the questioning of the public funding of culture at all-do not really appear in Bennett's work" (480). In other words, the policy primacy argument is very much fixed within the national borders of its source. 


\section{What is Culture?}

It is not, therefore, a matter of the inclusion or exclusion of policy issues that is in dispute in cultural studies. Neo-Gramscians like Angela McRobbie and Graeme Turner move comfortably from various modes of textual analysis into direct political and policy commentary, arguing consistently that the study of culture and the media must always return to the industrial and regulatory contexts in which media is formed, operates, and is consumed. Ien Ang concludes similarly that the move into a postmodern cultural epoch necessitates, rather than precludes, the full engagement of cultural studies in the industrial, professional, and ideological contexts within which media consumption takes place. According to Ang, media scholars are dutibound to investigate the broad gamut of textual production and consumption practices in order to elucidate fully the "living room wars" which are so powerfully implicated in the shaping of postmodern culture.

Ang's point here is that the divide between theorists of a postmodern cultural studies and those advocating some form of cultural civics is overstated. Ang's pragmatism reflects an increasing trend in cultural studies, one which comfortably engages with empirical, textual, and policy-based methodologies (see Storey, Grossberg, Grossberg et al.). However, this trans- or post-disciplinary perspective is tending to parenthesize substantive definitional and theoretical matters in order to "get on with the task of doing cultural studies." The danger is, of course, that these questions may be perpetually deferred, thus limiting the cogency, relevance, and efficacy of findings. To this extent, the question of "what is culture?" seems a necessary precursor to the more dramatic question of "what is cultural studies?"

While I have offered a more detailed answer to this question in my book $\mathrm{Cul}$ tural Studies, I want to suggest here that culture is fundamentally formed through modes of meaning-making and that while a definition of culture necessarily draws on anthropological and structural linguistic roots, current understandings must also account for the poststructural and postmodern lexica. In this sense, culture needs to be understood in the following terms:

1. Culture is an "assemblage" of imaginings and meanings. Culture is constructed by humans in order to communicate and create community. While society and community are assemblages of people, culture is an assemblage of imaginings and meanings. Authors like Castells have objected to the notion of cultural imagining because it lacks a certain empirical solidity. However, empirical and social theory have never comfortably addressed the notion of imagining and its role in aesthetics, identity formation, and the broader shaping of human realities. Culture begins with an imagining of the world about us; these imaginings are represented in some way. That is, they are formed in discourse, language, symbols, signs, and texts-all concepts applied to meaning systems. These imaginings and meanings, however, can never be fixed or solidified, but remain assemblages that can be dismantled through time, space, and human action. That is, the "system" into which meanings are formed is far from absolute and immutable. The meanings are 
put together for a purpose within a particular historical and spatial (material) context. Meaning systems are always subject to the return of imagining and vice versa. Imaginings and meanings operate to form one another, but they can never be relied on as stable and sustaining formations. Meaning and imagining can at any time confirm or destabilize one another.

2. Culture is an assemblage of imaginings and meanings that may be consonant, disjunctive, overlapping, contentious, continuous, or discontinuous. In other words, culture is always transitional, transformative, open, and unstable. While the sociological lineage has tended to treat language as fixed and orderly, meaning systems like language are capable of producing misunderstandings and non-meaning as well as meanings. At any one time, a culture can be subject to an infinite array of meaning disputes and gaps. There may be a "dominant" meaning or "dominant" ideology which attempts to amplify and direct meanings in particular ways, but a culture can never be closed since it is made up of competing interests and many different individuals and groups.

3. Culture is an assemblage of imaginings and meanings that may be consonant, disjunctive, overlapping, contentious, continuous, or discontinuous. These assemblages may operate through a wide variety of human social groupings and social practices. This means that we can speak of a family culture, a national culture, an ethnic culture, a global culture, a work culture, a religious culture, a university culture, a football culture, a technological culture, a gay culture, and so on. Certain cultures form around institutions which may be more or less extensive and durable. These institutions exhibit more or less consonant ideological, semiotic, ethical, aesthetic, and organizational characteristics. To this extent, individuals may be subject to the cultural meanings that are produced and imposed by large and historically enduring institutions such as governmental institutions, the "family," or media corporations.

An individual human subject may participate in many different cultures simultaneously. Each of these cultures may have its own system of meanings which articulates itself through norms and values, beliefs, political ideals, rituals, clothing styles, vocabulary, status positions, and so on. A meaning system, that is, has many different dimensions which are formed through-various levels of dominant values. In fact, each culture may be more or less rigid in the structure of its associations or assemblages. Rigid rules, for example, may apply to the culture of the biker gang; these rules may define power relationships, economy, the position of the rider in the road line, sexual practices, and clothing styles. Individuals may experience severe dissonance through their participation in different cultures. AMuslim living in the United States, for example, may wish to practice polygamy, even though this transgresses the rules and dominant ideologies of the national culture. Equally, a heroin user may experience significant dissonance in a professional workplace.

4. Culture is an assemblage of imaginings and meanings that may be consonant, disjunctive, overlapping, contentious, continuous, or discontinuous. These assemblages may operate through a wide variety of human social groupings and social practices. In contemporary culture these experiences 
of imagining and meaning-making are intensified through the proliferation of mass media images and information. The electronic media has exaggerated particular cultural trends and processes during the twentieth century. The particular characteristics of electronic communication have rendered the problem of cultural dispute, dissonance, instability, and transition more acute; it has also vastly extended the available resources for imagining and meaningmaking. Previously distant human cultural formations have been brought into greater propinquity, creating the circumstances for a proliferation of cultural discourses. These proliferating discourses stimulate ever-increasing possibilities for new meanings and new non-meanings or communication gaps.

\section{Transculturalism}

Richard Johnson's notion of culturalism sought to describe a certain theoretical coherence amongst the Birmingham cultural analysts and their followers. According to Johnson, culturalists believe that a social group's behavioral and social patterns could be revealed through the analysis of textual production and documented practices. While this centralization of the concept of culture is highly significant for those seeking a cogent rendering of human behaviors, aesthetics, and ideas, Johnson's concept of culturalism fails to appreciate adequately the complex nature of culture and the broad problematics of meaning-making as we have discussed it in this paper. In particular, culturalism only partially acknowledges the relationships between meaning and non-meaning, ideology and subjectivity, social reform, and social imagining.

The concept of "transculturalism" is offered as an advance on Johnson's original notion. Transculturalism mobilizes the definitions of culture outlined above through the expression and deployment of new forms of cultural politics. To put it simply, transculturalism adapts and extends both Gramscian and Foucaultian analysis in order to create a more critically potent and theoretically consistent mode of cultural investigation. Transculturalism can be characterized in the following terms-

- Transculturalism is distinguished, in particular, by its emphasis on the problematics of contemporary culture, most particularly in terms of relationships, meaning-making, and power formation. However, transculturalism is as interested in dissonance, tension, and instability as it is with the stabilizing effects of social conjunction, communalism, and organization. It seeks to illuminate the various gradients of culture and the ways in which social groups "create" and "distribute" their meanings. Equally, though, transculturalism seeks to illuminate the ways in which social groups interact and experience tension. It is interested in the destabilizing effects of non-meaning or meaning atrophy. It is interested in the disintegration of groups, cultures, and power. In other words, transculturalism emphasizes the transitory nature of culture as well as its power to transform. Transculturalism looks in particular toward the ways in which language wars are historically shaped and conducted. These language wars create the conditions of stability and instability as individuals and groups congregate, communicate, and seek to assert their material and semiotic interests over others. 
- Culture is formed in and around "language wars" which operate through all social levels and which may be more or less severe in terms of semiotic, personal, and material outcomes. Language wars are an inevitable part of human engagement; they are constituted through what Stuart Hall calls the "struggle to signify." Individuals and social groups engage in language wars as they attempt to communicate, form community, maximize personal gratifications, or create boundaries. In other words, language strategies may be deployed in order to constitute personal or social assemblages; they may also be used as a direct assault against other individuals and assemblages in order to manage, control, or destroy them.

- Transculturalism does not seek to privilege the semiotic over the material conditions of life, nor vice versa. Rather, it accepts that language and materiality continually interact within an unstable locus of specific historical conditions. However, our access to and knowledge of these material and historically defined conditions are necessarily filtered through an engagement with language and language wars. Transculturalism locates relationships of power in terms of language and history.

- Language wars have become more prolific and intense through the increasing propinquity of social groups, including propinquities created by the massive movement of people, information, and televisual images across the globe. Clearly, transculturalism engages with the broad field of debates surrounding globalization and internationalization. Transculturalism, however, identifies these multiply flowing processes in terms of a broadly contested and uneven distributions, disjunctures, and concentrations. Network and culture jamming, WEF protests, religious localisms, and the re-assertion of national sovereignties are all part of the language wars with which the counter-surges of economic and corporate globalism must contend.

- Power is ubiquitous and always implicated in meaning-making; however, meanings are fundamentally fluid and impossible to control in absolute terms. People create meanings through their various social assemblages and everyday practices. These social assemblages may intensify and expand, forming concentrations of power nodes (institutions, structures). These nodes and assemblages attempt to fix power and their meaning through various strategies of domination, including the formation of hegemonic and ideological discourses. This attempt to fix power and meaning, however, is critically divorced from the everyday practices and processes of meaning-making in which all subjects are engaged. The process of fixing transgresses the inevitable dynamic of meaning-making; signifiers are strained beneath the ossifying force of fixity, eventually splintering, fissuring, and separating in a process of dissociation. These dissociating signifiers - ruptured meaning, non-meaning, abandoned meaning - become the raw materials for the everyday meaning-making of social practitioners. The ossifying walls of the institutional meanings become brittle and the foundations of power collapse. New cultures and new meanings break out within the fissures and echoes of the structures that seem to contain them. 
- The transcultural critic cannot, however, stand idly by awaiting the implosion of these concentrations of power. As noted, culture and power nodes are formed out of language wars which necessarily produce a broad range of semiotic and physical casualties. In order to limit the damage caused by nodalization, transcultural critics must also be actively engaged in language warfare, bringing to bear our own knowledge, ethics, contentions, and beliefs. In particular, we must elucidate the processes of meaning formation, deconstruct their sources and identify nodalizations and the brutish infamies of social and cultural injustice. Transculturalism, that is, requires the critic to be actively engaged in deconstruction and re-construction.

- In this sense, the methods of the transcultural critic are varied and multitargeted. It must engage in the intellectual austerities of structuralism and cultural civics. It must engage in mediated and other aesthetics, noting that all social artifacts and practices constitute meaning production. In this way, de Certeauian and postmodern conceptions are incorporated into a broad visceral politics, which engages fully in all representational forms, including those shaped through human relationships, the body, and identity formation.

- For the transcultural critic difference is to be both welcomed and feared. Difference that is hideous or brutal, or which rejoices in the infamy of hurt or the intellectual containment of others, is to be repudiated. Transculturalism is not a capitulative or celebrational separationism. It is an engagement in language war, a radical disposition which participates in all modes and levels of social dialogue. It involves itself with community action, jamming and debates with the state. It is neither faithful nor faithless, but steers its path through the minutiae and the macrocosms of various cultural assemblages, claims, and power nodes.

- And finally, transculturalism is deeply suspicious of itself and of all utterances. Its claim to knowledge is always redoubtable, self-reflexive, and selfcritical. Transculturalism can never eschew the force of its own precepts and the dynamic that is culture. Transculturalism chooses the best option, action, or perspective from the matrix of claims. It recognizes the implausibility of a durable knowledge and the impossibility of truth beyond the moment. It deals, therefore, in options, perspectives, and strategies. The cultural patterns it encounters and illuminates are a manifestation of the transitory-meaningful only in a localized and erstwhile manner.

\section{9/11 and the Afghan War: By Way of Conclusion}

The assault on the World Trade Center represents a stunning and terrible escalation of language war. Innumerable commentators have found their explanation for the atrocity in terms of a discourse of "terror." Beyond the immediate sufferings of the victims and their loved ones, the force of public, media, and state attention has been directed toward the identification and punishment of these "terrorists." Identification in this sense refers both to the location of perpetrators and the ascription of characteristics and meanings. This process of identity ascription, as the cultural 
studies community understands very well, is a form of what Lacan calls a "double entry matrix": that is, the identity of the ascriber reflects across the identity of the ascribee (and vice versa). It is not at all surprising that each side of the language polemic refers to the other as "demonic," while identifying themselves as innocent, heroic, and victim.

Clearly, these language wars are associated more broadly with a long history of territorialism, suffering, and retribution. Numerous critics (e.g. Herman, Sontag, Chomsky) have pointed to the critical deficiencies of American foreign policies, especially in the Middle East. America's support for the oppressive regime in Saudi Arabia, US bombing in the Sudan, continuing sanctions against Iraq, the conscious neglect of the Palestinian problem, and the ongoing and destabilizing effects of CIA activities in the region are all clearly implicated in both the assaults of 9/11 and the reprisal attacks on the Taliban, Al Qaeda, and Afghanistan. As Susan Carruthers has argued, however, state policy cannot be isolated from other critical cultural elements; in particular, Carruthers argues, the confluence of state policy, public consent, and the media appear to have become a pre-condition of contemporary military warfare. In this sense, just as the media was directly implicated in the process of meaning construction during the Gulf War, public understanding and attitudes toward 9/11 and the Afghan war are clearly associated with media and the historical cultural conditions within which the rubric of state policy is formed (see Taylor, Norris, Baudrillard, Carruthers, Luow).

Noam Chomsky, in fact, suggests that the media complicitly surrenders its critical function during times of crisis in order to support national stability and security:

It is entirely typical for the major media, and the intellectual classes generally, to line up in support of power in a time of crisis and try to mobilize the population for the same cause. That was true, with almost hysterical intensity, at the times of the bombing of Serbia. The Gulf War was not at all unusual. (30)

This view is corroborated by Young and Jesser who argue that "opinion polls have shown overwhelming popular support for constraints on the media during recent limited conflicts" (11). The surging popularity of President Bush and the oft-cited 80 percent public support for the reprisal policies might seem further to substantiate this "consensus" of media, state, and public.

There is insufficient space in this essay to interrogate these analyses in any great detail; however, I want to suggest, by way of conclusion, that a transcultural reading of the 9/11 calamity would accommodate such interrogations while focusing on the transient, agonistic, and unstable cultural conditions in which the "war" is being waged. In this sense, the transcultural method doesn't begin its analysis with specific assumptions about state authority and the capacity of social elites, including the media, to "manufacture consent." Rather, transculturalism is interested in the specific instances and various gradients of power, including its formation, external and internal challenges, and impetus to defoliation or deconstruction. The task of criticism and reform is thus enabled by a more complete rendering of 
the cultural elements which are informing operations of policy, the media, and public opinion.

At their most obvious and as we have noted above, these language wars have centered on disputes over forms of self-ascription; the respective sides of the war define themselves in terms of an heroic crusade and the protection and "liberation" of self-determined cultural values. Less obvious, perhaps, are the ways in which the whole notion of the "United States" (and its constituent semiotic order) is both culturally constituted and simultaneously subject to discursive counter-claims and dispute. In this sense, the World Trade Center becomes implicated in both a direct material assault (economic, spatial, biological), as well as in a far more redolent and intense conflict over meaning. Built in 1972 by the Rockefeller dynasty, the World Trade Center was configured as an ensign of American enterprise and the capitalist dream. This propagated meaning seemed to inscribe itself more fully on the American imaginary following the terrorist bombings of 1993. The twin towers came to represent an heroic and defiant heritage, proudly defining the Manhattan skyline in terms of a US economic, political, and moral primacy. Amid the swarm of American economic and cultural exports, the twin towers might be identified as the center of New York, which is the center of America and the globe. But it is precisely this sort of "export of image" which renders the "United States" vulnerable to appropriation, adaptation, re-inscription, and critical semiotic dispute. It is quite clear, therefore, that the Trade Center assailants attached very different meanings to the towers and to the US generally than those intended by a remarkably introspective and insular American discursive hegemony. The Trade Center and the "United States" have been offered to the world, but the complexity of that world simply shatters the discursive borders that the American authorities (consciously or not) might seek to impose. America's power to coerce, its "strength," is critically limited by the freedom of others in the global "community" to make of their culture whatever they will—that culture includes the torrent of elements, actions, and texts that the US so unrestrainedly delivers to the world but whose meanings are open to dispute.

Clearly, George Bush's "shock" that anyone could "hate America" betrays an extraordinary solipsism and incapacity to understand this point. The broad global dissemination of American commerce and culture seems to obscure the complex and often contradictory attitudes that this global presence engenders. American foreign policy is textured by this same problematic, the same cultural ambit. As the peoples of the Middle East dispute over territories that have been defined by colonial cartographers, liberation movements, and international arbiters, they aspire to a conflux of contending and contiguous values drawn from a broad spectrum of cultural sources. Accordingly and as Edward Said has constantly argued, the values of "freedom" and self-determination that Bush, the free press, and First World authorities would bring to the region are unquestionably resonant for Middle Eastern peoples: protection from terror is as important to $\mathrm{Al}$ Qaeda as it is to the people who had been working in the Trade Center buildings on 9/11. However, as Said also maintains, the methods of delivery and the precise definition of these liberational values needs to accommodate the specific cultural characteristics of the peoples 
who are creating their lives and cultures within their specific social and historical contexts. The reduction of the Trade Center to rubble represents the communicative disjunctures and problems of contiguous cultural meaning-making as much as it is symptomatic of the inadequacies of American foreign policy, airport security, or CIA intelligence gathering.

This problematic of meaning-making and cultural contiguity is a critical factor in the formation of language war and power. However, as we have noted, a configuration like the "United States" seeks to form itself as a super-text, overriding and resolving the problematic through the imposition of a nodal and extraneous symbolic order. The much-vaunted consensus of state, media, and public attitudes toward the 9/11 and Afghan war might seem to support an assertion that a symbolic order is being re-asserted against the threat of external challenge. Our argument thus far would claim, on the contrary, that the divide between external and internal threat is obscured in a global cultural context. American culture is necessarily debordered by its presence and integration with other world cultures; challenges by Al Qaeda and others are formed through the integration of America into Middle Eastern cultural imaginings. Similarly, the agonisms which challenge American hegemony in world affairs may also be forged through trans-border affiliations, for example, between Muslims in the Middle East and Left or liberal intellectuals in America. For many of these American intellectuals, their embodiment in the "United States" is conditional and necessarily "amorphousized" by these identifications and contiguities with "external" peoples. Beyond these "external" challenges to the nodalized "United States," we would suggest further that the notional consensus of state, media, and public is both precarious and dubious. In fact, the carefully managed theatricizing of 9/11 and Afghan through what Luow refers to as a PR-izing of war, clearly demonstrates that the American authorities themselves recognize that public opinion is fundamentally volatile and transient. While critics like Noam Chomsky and Neil Postman have claimed that this volatility masks a more encased or essential gullibility, recent theorization on audiences and media consumption would suggest that such views profoundly underestimate the creative and liberational capacity of viewing publics (see Morley, Ang, Lull). In fact, the media-ization of politics and war illustrates a clear tension between the vulnerability and creativity of audiences-as-citizens. This tension is clearly associated with the processes of cultural televisualization (see Lewis 419-448): that is, the transformation of reality through televisual imagery. The volatility of public opinion reflects, therefore, the transient nature of imagery, the imprecision of mediated politics, and the disjunctive and incomplete character of televisual knowledge.

The pursuit of Osama bin Laden and his network needs ultimately to be placed within this cultural context. While we might suspect America of ulterior motives in the Middle East, most especially associated with oil interests, there remains a fundamental contradiction in the bin Laden pursuit and the "consent" of the American public to an execution without trial, deliberation, evidence, or judgement. Moreover, this pursuit and pre-emptive "punishment," which necessarily involves the invasion of a sovereign territory and the deaths, maiming, expatriation, and starvation of thousands of innocent Afghan people, clearly transgresses the fundamental 
principles of democracy and freedom. The legitimation of this transgression is, as Zolo warns, a condition of media or televisual politics. Indeed, just as the World Trade Center had been subjected to the extremes of language warfare, bin Laden himself has been inscribed with meanings that reach well beyond the specific character of the crime of which he is accused. This identity politicking is shaped through the US president's calculated but vaguely hysterical invocation of the Wild West and the Wanted Dead or Alive posters, a calling to frontier America which has itself been constituted through an hyperbolized Hollywood heroic, the sort of deadly madness evident in characters like Lt. Colonel Kilgore in Coppola's Apocalypse Now. This referencing to American film and TV culture, in fact, inflates the meanings of $9 / 11$ to such a degree that the intensity and constituent order of the event seem simultaneously to defoliate, shred themselves in an absurd gesture of violence that has already been seen, configured, and digested. Even as the airliners crash into the towers and the glass walls begin to implode in fire and dust it is as though the movie has already been screened a thousand times before. This is not merely fatalism, but a resonance of a self-obsessed televisual culture which has drained its imaginings into a deluge of self-explorations, introspections, and heroic self-assertions. Bush calls on the Wild West and the hero in the white hat because that is where America has already been, its culture already self-amazed, flagellated, and disseminated across the world.

It is this dimension of exhausted or dissociated meaning (non-meaning) which threatens the cultural configuration of the "United States" from within its own hegemonic impulses. This is not to risk a suggestion that 9/11 and the Afghan war "did not take place" as Baudrillard does of the Gulf War (see Baudrillard, Norris); it is rather to cast serious doubt over an excessive intellectual investment in notions like "semiotic order" and "consensus" as an absolute truth-condition without reference to countervailing immanent irruptions. It is to suggest, in fact, that the textual configuration of the "United States" is extremely volatile, transient, and subject to its own internal agonisms and propensities for deconstruction and defoliation. Bush's 2002 State of the Union Address, though propagated as a declaration of a linguistic and material order, indicates how quickly the consensus will unravel under the pressure of inevitable language war. The role of the transcultural critic, as I have suggested in this paper, is to participate in the persuasion games and language wars which surround and irradiate through these assertions of power. This is not "to speak on behalf of others," but rather to elucidate constituencies of discursive and material nodalization, exposing them to the conditions of analysis and critique. There can be no guarantees or principles of judgement beyond the claims of possibility. Our aim is to limit the damage created by nodalizing and agonistic processes and to provide new imaginings for new possibilities in the human experience. To this extent, Susan Sontag asks that America become "something more than strong" as it emerges from the ashes of Ground Zero. A broadened rendering of this "something more" might embrace the possibilities for peoples and groups across the globe. In this task, cultural studies should provide some invaluable guidance. 


\section{Works Cited}

Ang, Ien. Living Room Wars: Rethinking Media Audiences for a Postmodern World. London: Routledge, 1996.

Baudrillard, Jean. The Gulf War Did Not Take Place. Trans. Paul Patton. Bloomington: Indiana University Press, 1995.

Bennett, Tony. "Putting Policy into Cultural Studies." The Cultural Studies Reader. 2nd ed. Ed. Simon During. London: Routledge, 1999. 480-491.

Carruthers, Susan. The Media at War: Communication and Conflict in the Twentieth Century. London: Macmillan, 2000.

Castells, Manuel. The Power of Identity. London: Blackwell, 1997.

Chomsky, Noam. September 11. Crows Nest: Allen \& Unwin, 2001.

Deleuze, Gilles, and Felix Guattari. A Thousand Plateaus: Capitalism and Schizophrenia. Trans. Brian Massumi. Minneapolis: University of Minnesota Press, 1987.

During, Simon. "Editor's Introduction.” The Cultural Studies Reader. 2nd ed. Ed. During. London: Routledge, 1999. 479-480.

Fiske, John. Media Matters: Race and Gender in U.S. Politics. Minneapolis: University of Minnesota Press, 1996.

-. Understanding Popular Culture. Boston: Unwin Hyman, 1989.

Foucault, Michel. Discipline and Punish: The Birth of the Prison. Trans. Alan Sheridan. New York: Penguin, 1977.

-. "Governmentality." The Foucault Effect: Studies in Governmentality. Ed. G. Burchell, C. Gordon, and P. Miller. Chicago: University of Chicago Press, 1991. 87-104.

- The History of Sexuality Volume I: An Introduction. Trans. R. Hurley. New York: Penguin, 1981.

-. "Technologies of the Self." Technologies of the Self: A Seminar with Michel Foucault. Ed. Luther H. Martin, Huck Gutman, and Patrick H. Hutton. Amherst: University of Massachusetts Press, 1988. 16-49.

Giddens, Anthony. The Transformation of Intimacy: Sexuality, Love and Eroticism in Modern Societies. Cambridge: Polity, 1992.

Grossberg, Lawrence. Bringing It All Back Home: Essays on Cultural Studies. London and Durham: Duke University Press, 1997.

Grossberg, Lawrence, Ellen Wartella, and David Charles Whitney. Media-Making: Mass Media in Popular Culture. London: Sage, 1998.

Habermas, Jürgen. The Philosophical Discourse of Modernity: Twelve Lectures. Trans. Frederick Lawrence. Cambridge: MIT Press, 1987.

-. The Structural Transformation of the Public Sphere: An Inquiry into a Category of Bourgeois Society. Cambridge: MIT Press, 1989.

-. "Taking Aim at the Heart of the Present." Foucault: A Critical Reader. Ed. David Couzens Hoy. New York and Oxford: Basil Blackwell, 1986. 103-108.

Halberstam, Judith, and Ira Livingston. Posthuman Bodies. Bloomington: Indiana University Press, 1995.

Hall, Stuart. "Cultural Studies and its Theoretical Legacies." Stuart Hall: Critical Dialogues in Cultural Studies. Ed. David Morley and Kuan-Hsing Chen. London: Routledge, 1996. 262-275.

-. "The Local and the Global: Globalization and Ethnicity." Culture, Globalization and the World System. Ed. Anthony D. King. Binghamton: State University of New York at Binghamton Press, 1991. 19-39.

-. "Old and New Identities, Old and New Ethnicities." Culture, Globalization and the 
World System. Ed. Anthony D. King. Binghamton: State University of New York at Binghamton Press, 1991. 41-68.

- "The Rediscovery of Ideology: The Return of the Repressed in Media Studies." Culture, Society and the Media. Ed. M. Gurevitch et al. London: Methuen, 1982. 56-90. Herman, Edward. "Archive." Z Magazine. $2001<$ http://www.zmag.org>.

Jameson, Fredric. “On 'Cultural Studies.” Social Text 34 (Spring 1993): 17-52.

Johnson, Richard. "Three Problematics: Elements of a Theory of Working Class Culture." Working Class Culture: Studies in History and Theory. Ed. John Clarke. London: Hutchinson, 1979. 201-237.

Kellner, Douglas. "Cultural Theory and Cultural Studies: The Missed Articulation." Cultural Methodologies. Ed. Jim McGuigan. London: Sage, 1997. 12-41.

Lewis, Jeff. Cultural Studies. London: Sage, 2002.

Lull, James. Media, Communication, Culture: A Global Approach. New York: Cambridge, 1995.

Luow, Eric. The Media and Cultural Production. London: Sage, 2001.

McGuigan, Jim. Cultural Populism. London: Routledge, 1992.

—. Culture and the Public Sphere. London: Routledge, 1996.

McRobbie, Angela. Postmodernism and Popular Culture. London: Routledge, 1994.

Morley, David. Television Audiences and Cultural Studies. London: Routledge, 1992.

Nancy, Jean-Luc. The Inoperative Community. Trans. P. Conner. Minneapolis: Minneapolis University Press, 1991.

Norris, Christopher. Uncritical Theory: Postmodernism, Intellectuals and the Gulf War. London: Lawrence and Wishart, 1992.

Postman, Neil. Amusing Ourselves to Death: Public Discourse in the Age of Show Business. London: Methuen, 1987.

Said, Edward. Culture and Imperialism. London: Chatto and Windus, 1993.

Sontag, Susan. "Talk of the Town." The New Yorker 24 Sept. 2001: 32.

Storey, John. An Introduction to Cultural Theory and Popular Culture. London: Prentice Hall, 1998.

Taylor, P. M. War and the Media: Propaganda and Persuasion in the Gulf War. Manchester: Manchester University Press, 1992.

Turner, Graeme. British Cultural Studies: An Introduction. 2nd ed. London: Routledge, 1996.

Young, Peter, and Peter Jesser. The Media and the Military: From the Crimera to Desert Strike. New York: St. Martin's, 1997.

Zolo, Danilo. Democracy and Complexity. London: Polity Press, 1992. 